\title{
Antioxidant System Alterations and Biological Health Status of Earthworms Following Long-term Exposure to Antibiotics Contaminated Poultry Litter
}

Sidney Fernandes Sales Junior

Oswaldo Cruz Foundation: Fundacao Oswaldo Cruz

Evelyn Oliveira da Silva

Oswaldo Cruz Foundation: Fundacao Oswaldo Cruz

Gabriel de Farias Araujo

Oswaldo Cruz Foundation: Fundacao Oswaldo Cruz

Lorena Oliveira Souza Soares

UNIRIO: Universidade Federal do Estado do Rio de Janeiro

Cláudio Ernesto Taveira Parente

UFRJ: Universidade Federal do Rio de Janeiro

Olaf Malm

UFRJ: Universidade Federal do Rio de Janeiro

Enrico Mendes Saggioro ( $\nabla$ saggi_br@hotmail.com )

Oswaldo Cruz https://orcid.org/0000-0002-6072-6749

Fábio Veríssimo Correia

UNIRIO: Universidade Federal do Estado do Rio de Janeiro

\section{Research Article}

Keywords: Antibiotics, Enrofloxacin, Oxidative stress, Eisenia andrei, Biomarker response index

Posted Date: June 22nd, 2021

DOl: https://doi.org/10.21203/rs.3.rs-595228/v1

License: (1) This work is licensed under a Creative Commons Attribution 4.0 International License.

Read Full License

Version of Record: A version of this preprint was published at Environmental Science and Pollution Research on November 22nd, 2021. See the published version at https://doi.org/10.1007/s11356-02117599-9. 


\section{Abstract}

Poultry litter is widely applied as a fertilizer even though it is one of the main antibiotic sources for agricultural soils. Long-term sublethal effects (56 days) on the antioxidant system of Eisenia andrei earthworms following exposure to fluoroquinolone-contaminated poultry litter (enrofloxacin + ciprofloxacin) at 5.0, 10 and $20 \mathrm{~g} \mathrm{~kg}^{-1}$ were evaluated. The following biomarkers were assessed: superoxide dismutase (SOD), catalase (CAT), glutathione-S-trasferase (GST), reduced glutathione (GSH) and a lipid peroxidation (LPO) proxy. Significant CAT and SOD increases and a moderate positive correlation $(\rho=0.67, p<0.05)$ between these enzymes was observed. Glutathione-S-trasferase levels increased significantly at $10 \mathrm{~g} \mathrm{~kg}^{-1}$, while GSH exhibited a dose-dependent response at $5.0 \mathrm{mg} \mathrm{kg}^{-1}(4$ $106 \%), 10 \mathrm{mg} \mathrm{kg}^{-1}$ (28 - $330 \%$ ) and $20 \mathrm{mg} \mathrm{kg}^{-1}$ (45 - 472\%). LPO levels exhibited a decreasing trend with increasing poultry litter concentrations of $8-170 \%\left(5.0 \mathrm{~g} \mathrm{~kg}^{-1}\right), 7-104 \%\left(10 \mathrm{mg} \mathrm{kg}^{-1}\right)$ and $3-6 \%(20 \mathrm{mg}$ $\mathrm{kg}^{-1}$ ). A Principal Component Analysis (PCA) highlighted increased SOD and CAT activities, possibly due to increases in reactive oxygen species (ROS) concentrations. Biological Health Status assessments based on the Biomarker Response Index indicate major alterations in the first month of exposure, changing to moderate in the second month. These findings indicate an antioxidant system attenuation trend. It is possible, however, that successive poultry litter applications may reduce the long-term recovery capacity of the evaluated biomarkers.

\section{Introduction}

Global poultry meat production has increased in recent decades, estimated at around 137 million tons in 2020 , the equivalent to $41 \%$ of the world's total meat production (FAO 2020; Fortuna et al. 2020). The main poultry industry residue, poultry litter, is widely applied in agricultural soils as a fertilizer (Bolan et al. 2010; Dróżdż et al. 2020). Estimates indicate that Brazil, the world's main poultry meat exporter, produces about 8 to 10 million poultry litter tons/year (Santos Dalólio et al. 2017; ABPA 2020). Poultry litter application in soils is widespread, as this residue contains high concentrations of nitrogenous compounds and other macronutrients, such as calcium, phosphorus, magnesium and potassium, while also contributing to organic matter soil input and with the increase water retention and cation exchange capacity (Vollú et al. 2018; Parente et al. 2020). In this context, the use of poultry litter as a fertilizer is aligned with the UN's Sustainable Development Goals (United Nations 2020), as a practice that promotes the sustainability and resilience of agricultural environments. On the other hand, poultry litter is a complex matrix composed of a vegetable substrate (i.e., rice husks, pines and Eucalyptus spp. sawdust), feed, water, manure and feathers, as well as pathogens and veterinary drugs used as growth promoters or for prophylaxis and therapy (Parente et al. 2018; Dróżdż et al. 2020; Kanani et al. 2020).

In this context, previous studies have reported the presence of antibiotics (e.g. macrolides, sulfonamides, tetracyclines and fluoroquinolones - FQs) and antibiotic resistant bacteria or genes in poultry litter and soil samples from Brazil (Leal et al. 2012; Parente et al. 2019), Canada (Furtula et al. 2010), China (Wei et al. 2019; Gu et al. 2019) and the United States (Cook et al. 2014). Among antibiotics, FQ have attracted 
special attention due to their wide environmental occurrence, soil persistence and adverse effects on terrestrial organisms (Riaz et al. 2018; Yang et al. 2021). Considering that soils may be associated with multiple contaminants, a trend towards toxicological assessments based on two or more active principles have been proposed (Li et al., 2016; Wang et al., 2019; Wei et al., 2018). For example, an association between the FQ ciprofloxacin (CPX) and oxytetracycline at 1.0 and $5.0 \mathrm{mg} \mathrm{kg}^{-1}$ was shown to directly affect soil protist abundance and bacterial diversity, altering trophic relationships and soil microbiota equilibrium (Nguyen et al. 2020). In a study carried out with Eisenia fetida earthworms, Li et al. (Li et al. 2016) reported that increasing enrofloxacin (ENR) concentrations from 1.0 to $10 \mathrm{mg} \mathrm{kg}^{-1}$ influenced cadmium (Cd) bioaccumulation and oxidative stress responses. Advancing towards a greater effectiveness of ecotoxicological assessments, evaluations based on complex matrices (e.g. biosolids, sewage sludge and poultry litter) result in important information concerning the risks of applying these materials to soil quality and biodiversity (Sidhu et al. 2019; Rivier et al. 2019; Zhang et al. 2019). In this context, poultry litter effect assessments on terrestrial organisms are still scarce. Maccari et al. (2020), for example, observed negative effects on springtail reproduction (Folsomia candida), resulting in an effective concentration for $50 \%$ of the exposed organisms $\left(E_{50}\right)$ of $7.5 \mathrm{~g} \mathrm{~kg}^{-1}$. Testa et al. (2020) reported effects on the reproduction of Enchytraeus crypticus soil worms exposed to $5.0 \mathrm{~g} \mathrm{~kg}^{-1}$ poultry litter containing the pyrethroid insecticide cypermethrin. With regard to earthworms, lethal, behavioral, reproductive and cytotoxic effects have recently been reported for Eisenia andrei exposed to FQcontaminated poultry litter (Parente et al. 2021). In addition, recent studies have demonstrated that oxidative stress molecular biomarkers are suitable for assessing sublethal effects in earthworms following long-term exposure to contaminants (Niva et al. 2016; Saggioro et al. 2019; Sales Junior et al. 2020).

In this context, the aim of the present study was to evaluate antioxidant system and oxidative effects in Eisenia andrei earthworms exposed to FQ-contaminated poultry litter at concentrations in the same range of real-life agricultural soil applications. To this end, poultry litter contaminated by the FQs ENR and CPX was used to evaluate alterations in the following biomarkers: superoxide dismutase (SOD), catalase (CAT), glutathione-S-transferase (GST) and reduced glutathione (GSH), in addition to lipid peroxidation (LPO) using malondialdehyde (MDA) as a proxy for this oxidative stress endpoint. Furthermore, the biological health status (BHS) of FQ-exposed earthworms was calculated based on the biomarker response index (BRI), integrating the results of this experimental study into an environmentally relevant context.

\section{Material And Methods}

\subsection{Poultry litter sample, soil characteristics and test organisms}

The chemical characterization (antibiotics - ENR and its metabolite CPX, trace elements, $\mathrm{pH}$, cation exchange capacity and organic matter) of the poultry litter and soil samples used in the present study 
have been previously reported by Parente et al. (Parente et al. 2021). The poultry litter sample was obtained from a farm located in the largest poultry production center in the state of Rio de Janeiro, southeastern Brazil. The determined ENR $\left(23.6 \mathrm{mg} \mathrm{kg}^{-1}\right)$ and its metabolite CPX $\left(6.74 \mathrm{mg} \mathrm{kg}^{-1}\right)$ concentrations are in the same range as the reported maximum (ENR + CPX) detected in poultry litter samples from Brazil (33.1 $\mathrm{mg} \mathrm{kg}^{-1}$ ) (Leal et al. 2012) and poultry manure from China (18.1 $\left.\mathrm{mg} \mathrm{kg}^{-1}\right)$ (Li et al. 2015), constituting a critical exposure scenario. Detected metals reflect the addition of inorganic compounds used as growth promoters present in poultry feed (Parente et al. (Parente et al. 2021).

The soil used herein, a Red-Yellow Ultisol as established by the Brazilian System of Soil Classification (EMBRAPA, 2013), one of the most representative soils in Brazil, is composed of sand $\left(605 \mathrm{~g} \mathrm{~kg}^{-1}\right)$, silt $\left(107 \mathrm{~g} \mathrm{~kg}^{-1}\right)$ and clay $\left(288 \mathrm{~g} \mathrm{~kg}^{-1}\right)$. The metal concentrations in the soil sample used by Parente et al. (Parente et al. 2021) are well below the prevention limit established as a quality reference by Brazilian legislation (Hagger et al. 2008).

Eisenia andrei earthworms were cultivated at the Oswaldo Cruz Foundation Toxicology Laboratory (Rio de Janeiro, Brazil) in bovine manure at $20 \pm 2{ }^{\circ} \mathrm{C}$ and a $16 \mathrm{~h}$ :8h photoperiod (400 lux) according to the ASTM E1676 standard (ASTM 2012). The sensitivity of the earthworm batch used in the experiments was determined by an acute contact test (OECD, 1984), with an average lethal concentration $\left(\mathrm{LC}_{50}\right)$ of $5.15 \pm$ $0.28 \mu \mathrm{g} \mathrm{cm}^{-2}$. All experiments were carried out with adult organisms ( 2 to 3 months old) displaying a welldeveloped clitellum and body mass 0.3 to $0.6 \mathrm{~g}$.

\subsection{Poultry litter exposure set-up}

The chronic test was performed according to OECD standard no. 222 (2016) with adaptations proposed by the ASTM E1676 standard (ASTM 2012). During the test, temperature $\left(20 \pm 2{ }^{\circ} \mathrm{C}\right), 12 \mathrm{~h}$ photoperiod (400 lux) and soil humidity between 40 and $60 \%$ water retention capacity (WRC) were maintained and monitored. Assay validation consisted in control earthworm lethality (in all treatments) and biomass variations not exceeding $10 \%$ at the end of the assays (ASTM 2012).

The assay consisted of four $400 \mathrm{~mL}$ beaker replicates for each concentration. A total of $200 \mathrm{~g}$ of soil mixed with poultry litter $\left(5.0,10\right.$ and $\left.20 \mathrm{~g} \mathrm{~kg}^{-1}\right)$ was humidified with $35 \mathrm{~mL}$ of water. The proposed concentrations ranged from 45 to $85 \%$ below the 7-day LC $_{50}$ estimated by Parente et al. (Parente et al. 2021), to ensure no earthworm lethality during the chronic trial. The exposure groups were compared to a control group consisting of four replicates maintained in natural soil moistened with $35 \mathrm{~mL}$ of water. Replicates consisted in 10 earthworms maintained in vessels covered with perforated parafilm to favor oxygenation and prevent earthworm escape. The chronic test lasted 56 days with weekly openings $(7,14$, $21,28,35,42,49$ and 56 days) to collect five earthworms for antioxidant system biomarker evaluations regarding SOD, CAT, GST and GSH and the oxidative effect biomarker MDA. Moisture was corrected every 7 days and $5 \mathrm{~g}$ of bovine manure were added as earthworm feed. 


\subsection{Antioxidant system determinations}

After each weekly collection, the earthworms were individually crushed and homogenized in plastic test tubes containing $2.0 \mathrm{~mL}$ of a Lumbricus Balanced Saline Solution (LBSS) using an IKA T18 Basic Ultra Turrax shredder for 60 seconds at 1,000 rpm, followed by centrifugation at $885 \mathrm{xg}$ for 5.0 min using an 5430R microcentrifuge (Eppendorf, São Paulo, Brazil) (Saggioro et al. 2019). The supernatants were stored in microtubes at $-80^{\circ} \mathrm{C}$ prior to further analyses. Each biomarker was diluted as follows (volume/volume - v/v): 30:1 SOD; 50:1 CAT; 4:1 GST and 5:1 GSH.

SOD [Cu/Zn-SOD (cytoplasmic), Mn-SOD (mitochondrial) and Fe-SOD (extracellular)] enzymatic activities were determined by a colorimetric method using the SOD Assay Kit (Cayman Chemical Company, Michigan, US). A calibration curve was prepared with a SOD standard. Briefly, $200 \mu \mathrm{L}$ of the tetrazolium salt, $10 \mu \mathrm{L}$ of each sample and curve standards and $20 \mu \mathrm{L}$ of xanthine oxidase were added to microplate wells, followed by incubation for $30 \mathrm{~min}$ in the dark and absorbance determinations at $\lambda_{\max }=450$ nm using an Expert Plus microplate reader (Asys, São Paulo, Brazil).

CAT activity was determined according to Aebi (Aebi 1984), where enzymatic kinetics were determined by the addition of $1.0 \mathrm{~mL} \mathrm{H}_{2} \mathrm{O}_{2}(30 \% \mathrm{v} / \mathrm{v})$ at $30 \mathrm{mmol} \mathrm{L}^{-1}$ and $2.0 \mathrm{~mL}$ of each sample in a $3.0 \mathrm{~mL}$ quartz cuvette and absorbance determinations at $\lambda_{\max }=240 \mathrm{~nm}$ for $15 \mathrm{sec}$ using a UV-Vis V-530 spectrophotometer (Jasco, São Paulo, Brazil).

GST activity was determined according to Habig et al. (Habig et al. 1974), by quantifying the S-(2,4Dinitrophenyl-glutathione (GS-DNB) produced by the action of this enzyme in $30 \mathrm{mmol} \mathrm{L}^{-1}$ of GSH and 30 $\mathrm{mmol} \mathrm{L}^{-1}$ of 1-chloro-2,4-dinitrobenzene (CDNB). A total of $100 \mathrm{~mL}$ of the investigated sample, $100 \mu \mathrm{L}$ of GSH and $100 \mu \mathrm{L}$ of CDNB in $2700 \mu \mathrm{L}$ of a phosphate buffered solution (PBS) were added to a $3.0 \mathrm{~mL}$ quartz cuvette followed by absorbance determinations at $\lambda_{\max }=340 \mathrm{~nm}$ for $60 \mathrm{sec}$.

GSH quantification followed the method established by Wilhelm Filho et al. (Wilhelm Filho et al. 2005), adapted for microplate reader determinations. This biomarker was extracted in sodium phosphate buffer $0.1 \mathrm{~mol} \mathrm{~L}^{-1}, \mathrm{pH} 6.5$, containing $0.25 \mathrm{~mol} \mathrm{~L}^{-1}$ sucrose and $1.0 \mathrm{mmol} \mathrm{L}^{-1}$ EDTA, followed by centrifugation for $30 \mathrm{~min}$ at $11,000 \mathrm{~g}$ on an Eppendorf 5430R microcentrifuge (Eppendorf, São Paulo Brazil). A total of $350 \mu \mathrm{L}$ of each sample were mixed with $350 \mu \mathrm{L}$ of 2,2'-dinitro-5,5'-dithiodibenzoic acid (DTNB) at 0.25 mmol L-1, incubated in the dark for $15 \mathrm{~min}$ and analyzed at $\lambda_{\max }=412 \mathrm{~nm}$. Total proteins were quantified according to Bradford (Bradford), adapted for microplate reader determinations.

\subsection{Lipid peroxidation}

Oxidative effects were determined by the quantification of MDA, a lipid peroxidation by-product, according to Esterbauer and Cheeseman (Esterbauer and Cheeseman 1990), using the same lysate used for the antioxidant biomarker analyses. Briefly, a total of $150 \mu \mathrm{L}$ of diluted samples (5: $1 \mathrm{v} / \mathrm{v}), 150 \mu \mathrm{L}$ of 
$10 \%$ trichloroacetic acid and $1200 \mu \mathrm{L}$ of thiobarbituric acid (TBA) $0.53 \%$ in an acidic solution (AcOH $20 \%$

$+\mathrm{NaOH} 0.7 \mathrm{~mol} \mathrm{~L}^{-1}$ ) were pipetted into microtubes and incubated for $60 \mathrm{~min}$ at $100^{\circ} \mathrm{C}$, followed by an ice bath for $10 \mathrm{~min}$ and centrifugation at $1,600 \mathrm{xg}$ for another $10 \mathrm{~min}$. The samples were then analyzed in quartz cuvettes at $\lambda_{\max }=535 \mathrm{~nm}$.

\subsection{Biological health status (BHS)}

The biological health status (BHS) based on the biomarker response index (BRI) (Hagger et al. 2008; Li et al. 2019) is calculated through the following steps.

Step 1: alteration levels (AL) are calculated from the response of each biomarker (Equation 1).

$$
A L=\frac{\left(B R_{t}-B R_{c}\right)}{B R_{c}}
$$

Where $\mathrm{BR}_{\mathrm{t}}$ is the biomarker response observed in treated soils and $\mathrm{BR}_{\mathrm{c}}$ comprises the control response, both considering replicate means.

Step 2: each AL receives a score according to the percentage of deviation from the controls, ALs with a deviation greater than $\pm 100 \%$ in relation to the control group were assigned a score of 1 , ALs between $\pm 50 \%$ and $\pm 100 \%$ with respect to the controls received a score of 2 ; ALs ranging between $\pm 20 \%$ and $\pm 50 \%$ were assigned a score of 3 , and ALs with a deviation of less than $\pm 20 \%$ in relation to the control group received a score of 4 .

Step 3: the weightings of each biomarker are defined according to the biological action mechanisms (Piva et al. 2011). A weighting of 1.0 is assumed for individual antioxidant biomarkers, as their activities do not necessarily imply in a toxicity threshold, and a weighting of 1.2 is set for MDA, a biomarker related to adverse effects, such as lipid peroxidation.

Step 4: the biomarker response index (BRI) is calculated through Equation 2 (Hagger et al. 2008).

$$
\boldsymbol{B R I}=\frac{\sum\left(s_{n} \times W_{n}\right)}{\sum W_{n}}
$$

Where $S_{n}$ is the score (step 2) and $W_{n}$ is the weight (step 3) of each biomarker " $n$ ".

Step 5: finally, the BRI values are classified into four BHS levels, ranging from $1.0-2.5$ (BHS = severe alteration); 2.51 - 2.75 (major alteration); $2.76-3.00$ (moderate alteration); $3.01-4.00$ (slight alteration) (Hagger et al. 2008).

\subsection{Statistical analyses}


Data normality was verified using the Shapiro-Wilk test. Comparisons between exposed samples and controls were performed through a one-way ANOVA analysis followed by Dunnett's post hoc test. The Kruskal-Wallis test followed by Dunnett's post hoc test was used for non-normally distributed data. Pearson's correlation tests and a Principal Component Analysis (PCA) were performed to investigate potential associations between the antioxidant system biomarkers and lipid peroxidation levels.

Correlation values (both negative and positive) between 0.0 and 0.2 are considered negligible, between 0.3 and 0.5 , weak, between 0.6 and 0.7, moderate and between 0.8 and 1.0, strong (Fávero and Belfiore, 2015). Comparisons between means and graph plotting were both carried out using the GraphPad Prism software, while the Pearson and PCA correlations were determined using the R program version 3.5.2. All analyses were performed using a confidence limit equal to or greater than $95 \%(p<0.05)$.

\section{Results And Discussion}

\subsection{Chronic experiment validation}

No deaths were observed in any of the chronic exposures, and the variations between the initial and final biomass were always less than 10\% (data not shown), indicating test validity (ASTM 2012). The chronic test concentrations (5.0, 10 and $20 \mathrm{~g} \mathrm{~kg}^{-1}$ ) did not generate any escape effects, lethargy or feeding behavior changes in the exposed organisms. In addition, these concentrations are equivalent to poultry litter and animal manure applications in agricultural soils $\left(10\right.$ to $\left.>40 \mathrm{t} \mathrm{ha}^{-1}\right)$ (Freire et al. 2013; Bhering et al. 2020).

\subsection{Antioxidant system}

\subsubsection{SOD and CAT activities}

The antioxidant system assessments indicated a significant increase $(p<0.05)$ in SOD activity compared to the controls on days 14, 21 and 35 (Fig. 1A). In addition, a wide range of enzyme activity variations was observed compared to controls, more pronounced in the $5.0 \mathrm{~g} \mathrm{~kg}^{-1}(36-316 \%)$ and $10 \mathrm{~g} \mathrm{~kg}^{-1}(18$ $204 \%$ ) treatments, followed by a decreasing trend in the $20 \mathrm{~g} \mathrm{~kg}^{-1}$ exposure (20 - 123\%). CAT activity (Fig. 1B) increased significantly on all evaluated days, except for the $28^{\text {th }}$, where only an upward trend was detected. Regarding the exposure treatments, the following variations were observed: $35-96 \%$ in the $5.0 \mathrm{~g}$ $\mathrm{kg}^{-1}$ treatment, $4-139 \%$ in the $10 \mathrm{~g} \mathrm{~kg}^{-1}$ treatment and $4-127 \%$ in the $20 \mathrm{~g} \mathrm{~kg}^{-1}$ treatment. CAT exhibited similar behavior to SOD, where a moderate positive correlation ( $\rho_{\text {SODXCAT }}=0.67, p<0.05$ ) was detected. This indicates that exposure to poultry litter generated the accumulation of the superoxide radical $\left(\mathrm{O}_{2}{ }^{-}\right)$, which was then transformed by SOD into hydrogen peroxide $\left(\mathrm{H}_{2} \mathrm{O}_{2}\right)$, increasing CAT levels (Barreiros et al. 2006). 
Previous studies on earthworms after exposure to the FQs ENR and CPX reported changes in the oxidizing system, including increased SOD and CAT activities (Gao et al. 2008; Wang et al. 2018). Wang et al. (Wang et al. 2018), for example, observed a significant increase in SOD activity in Eisenia fetida earthworms exposed to 3.2 and $6.4 \mathrm{mg} \mathrm{kg}^{-1} \mathrm{CPX}$ in an alkaline soil (pH 8.0). The effect reported by the authors occurred in the same CPX concentration range $\left(6.74 \mathrm{mg} \mathrm{kg}^{-1}\right)$ determined in the poultry litter used in the present study Parente et al. (Parente et al. 2021). In another study, Eisenia fetida exposure to ENR at an extreme concentration of $5,000 \mathrm{mg} \mathrm{kg}^{-1}$ during 2 and 14 days resulted in increased CAT levels, 2.2and 1.5-fold above the controls, respectively (Gao et al. 2008). The same effect was observed in the present study, with an increase in CAT activity up to 2.4-fold higher compared to the control group after 35 days of exposure to poultry litter containing a much lower ENR concentration $\left(23.6 \mathrm{mg} \mathrm{kg}^{-1}\right)$.

Furthermore, Wang et al. (Wang et al. 2018) demonstrated that CPX concentrations between 0.05 and 0.8 $\mathrm{mg} \mathrm{kg}^{-1}$ (130- and 8-fold lower than that in the poultry litter, respectively) resulted in increased CAT activity in Eisenia fetida earthworms. However, poultry litter is a complex matrix and changes in SOD and CAT activities may also be associated with a synergic association between FQ and metals present in the poultry litter. Copper $\left(\mathrm{CuSO}_{4}\right)$ and iron $\left(\mathrm{FeSO}_{4}\right)$ sulfate, for example, are added to poultry feed, while magnesium oxide $(\mathrm{MgO})$ composes the quicklime used in the treatment of poultry sheds (Parente et al. 2020). Therefore, the poultry litter used in the present study contains relevant concentrations of $\mathrm{Cu}$ (42.0 $\left.\pm 8.50 \mathrm{mg} \mathrm{kg}^{-1}\right)$, Fe $\left(145 \pm 34.2 \mathrm{mg} \mathrm{kg}^{-1}\right)$ and Mg (597 $\left.\pm 141 \mathrm{mg} \mathrm{kg}^{-1}\right)$ (Parente et al., 2021). These metals participate in cellular oxidative processes, such as the oxidation of glucose and other $a$-hydroxydehydes, resulting in $\mathrm{H}_{2} \mathrm{O}_{2}$ accumulation (Wolff and Dean 1987; Radetski et al. 2004; Bakare et al. 2012). In addition, calcium, present in quicklime composition as calcium oxide [CaO or hydrated $\left.\mathrm{Ca}-\mathrm{Ca}(\mathrm{OH})_{2}\right], w a s$ also detected in high concentrations in the poultry litter (3,004 $\left.\pm 813 \mathrm{mg} \mathrm{kg}^{-1}\right)$ (Parente et al. 2021), which may induce NADPH-oxidase activity, also resulting in $\mathrm{H}_{2} \mathrm{O}_{2}$ accumulation (Barbosa et al. 2014). The results, therefore, suggest $\mathrm{H}_{2} \mathrm{O}_{2}$ accumulation caused by $\mathrm{O}_{2}{ }^{-}$- dismutation carried out by SOD and also by the presence of certain metals in the poultry litter, resulting in increased CAT activity.

\subsubsection{GST activity and GSH concentrations}

The GST analysis (Fig. 2A) revealed a significant increase in this enzyme's activity in the $10 \mathrm{~g} \mathrm{~kg}^{-1}$ treatment on all exposure days and in the $20 \mathrm{~g} \mathrm{~kg}^{-1}$ treatment on days 7, 21 and 42. This increase ranged from 1 to $84 \%$ in the $5.0 \mathrm{~g} \mathrm{~kg}^{-1}$ treatment, from 25 to $377 \%$ in the $10 \mathrm{~g} \mathrm{~kg}^{-1}$ treatment and from 8 to $94 \%$ in the $20 \mathrm{~g} \mathrm{~kg}^{-1}$ treatment.

GST is part of the glutathione transferase family, whose function is to catalyze nucleophilic GSH attacks on compounds containing carbon, nitrogen or sulfur, participating in detoxification and elimination mechanisms (Huber et al. 2008). In this sense, GST plays an essential role in catalyzing the formation of adducts between antibiotics and GSH, leading to compound inactivation (Pugazhendhi et al. 2017). This enzyme can also act in the detoxification of $a, \beta$-unsaturated compounds such as aldehydes and quinones, lipid peroxidation by-products (Huber et al. 2008). In addition, veterinary drugs and 
environmental contaminants present in the poultry litter (Parente et al. 2018; Dróżdż et al. 2020; Kanani et al. 2020) can be used as exogenous GST substrates (Hayes et al. 2005), which may also support the increased GST activities observed in the present study. In accordance with the detected GST increase at 14 days following exposure to the lowest poultry litter concentration $\left(5.0 \mathrm{mg} \mathrm{kg}^{-1}\right)$, Wang et al. (Wang et al. 2018) reported increased GST activity in Eisenia fetida exposed to CPX (6.4 and $12.8 \mathrm{mg} \mathrm{kg}^{-1}$ ) after 15 days of exposure.

Another factor that may influence increased detoxification capacity (and GST activity) comprises the stimulation of the gene expression of cytochrome P450 enzymes (CYP 450) in the presence of ENR (Li et al. 2018). These authors observed that ENR at concentrations up to $10 \mathrm{mg} \mathrm{kg}^{-1}$ led to increases in CYP 450 expression in Eisenia fetida earthworms. On the other hand, higher ENR concentrations (from $100 \mathrm{mg}$ $\mathrm{kg}^{-1}$ ) reduced the detoxification capacity of exposed earthworms (Li et al. 2018). In a matrix-based approach, Curi et al. (2017) observed decreased GST activity in anuran larvae (Leptodactylus chaquensis) exposed to poultry litter at high concentrations (125 and $250 \mathrm{~g} \mathrm{~kg}^{-1}$ ). Exposure to concentrations 10-fold higher than those applied in the present study resulted in increased cell membrane peroxidation processes, possibly leading to antioxidant system depletion and impairing the enzymatic biosynthesis of GST (Curi et al. 2017; Dionísio et al. 2020). In view of the observed results, the presence of contaminants commonly associated with poultry litter (e.g. antibiotics and trace elements) may play a key role in these processes, acting synergically with GST activity and detoxification mechanisms. In this context, the cytotoxic effects observed in earthworms after exposure to FQ-contaminated poultry litter (Parente et al. 2021), may be due to reduced detoxification capacity, resulting in xenobiotic accumulation in the intracellular medium.

The GSH tripeptide, associated with GST, participates in the glutathione redox cycle and is considered the main antioxidant system line of defense against reactive oxygen species (ROS) (Sies 1999; Bhagat et al. 2016; Simioni et al. 2018). The GSH results observed herein indicate a significant raise with increasing variations throughout the experiment (Fig. 2B), from 4 to $106 \%$ at $5.0 \mathrm{mg} \mathrm{kg}^{-1}, 28$ to $330 \%\left(10 \mathrm{mg} \mathrm{kg}^{-1}\right)$ and 45 to $472 \%$ (20 mg kg-1). The observed increase was characterized by a dose-dependent behavior, mostly in the final half of the experiment, while decreased GSH levels were observed during the first weeks (7, 14 and 28 days). Following exposure to $5 \mathrm{mg} \mathrm{kg}^{-1}$, a $45 \%$ decrease (28 days) was observed, while a $10 \mathrm{mg} \mathrm{kg}^{-1}$ exposure resulted in a decrease between 20\% (7 days) and 28\% (28 days). These results suggest that exposure to poultry litter generated a high demand for GSH through the glutathione redox cycle in order to reduce $\mathrm{H}_{2} \mathrm{O}_{2}$ accumulation, as well as in the detoxification process. Finally, from the $35^{\text {th }}$ day of exposure, a significant increase in GSH levels was observed. In an experiment following Eisenia fetida exposure to CPX (10 mg kg-1), Yang et al. (Yang et al. 2020) also initially observed a significant decrease in GSH levels (14 and 21 days). According to the authors, this indicates a critical phase associated with higher oxidative stress conditions and potential for cell damage, followed by a significant increase in GSH levels at 28 days. In an experiment with green algae (Chlorella vulgaris) exposed to ENR $\left(0.03 \mathrm{mg} \mathrm{L}^{-1}\right)$, erythromycin $\left(0.02 \mathrm{mg} \mathrm{L}^{-1}\right)$ and both antibiotics $\left(0.01 \mathrm{mg} \mathrm{L}^{-1}\right)$, GSH levels 
increased 1.85-, 1.71- and 2.28-fold above the control, respectively, demonstrating a synergistic effect even at low concentrations (Wang et al. 2019a). In another study carried with Chlorella vulgaris, Nie et al. (2008) observed that CPX $\left(<0.5 \mathrm{mg} \mathrm{L}^{-1}\right)$ led to decreased GSH levels after 14 days, while higher concentrations ( $\left.>12.5 \mathrm{mg} \mathrm{L}^{-1}\right)$ induced increases after 14 days. According to the authors, increased GSH levels can be due to ROS production derived from the CPX metabolism by the CYP 450 enzyme system, leading to the activation of the 7-glutamylcysteine synthase and glutathione synthase enzymes.

\subsection{Lipid peroxidation}

The MDA results indicated significant lipid peroxidation increases on days 7, 21, 28, 35 and 49 and a trend toward lower variations with increasing poultry litter concentrations, from 8 to $170 \%$ in the $5.0 \mathrm{~g} \mathrm{~kg}^{-1}$ exposure, 7 to $104 \%$ in the $10 \mathrm{mg} \mathrm{kg}^{-1}$ and 3 to $6 \%$ in the $20 \mathrm{mg} \mathrm{kg}^{-1}$ exposure (Fig. 3). A moderate increase in MDA levels was also observed on days 14, 21 and 56 following the $10 \mathrm{mg} \mathrm{kg}^{-1}$ exposure $(25,7$ and $45 \%$, respectively).

In an experiment carried out on Eisenia fetida earthworms exposed to ENR (1.0 and $\left.10 \mathrm{mg} \mathrm{kg}^{-1}\right)$, Li et al. (Li et al. 2016) observed increases in MDA levels only at the highest concentration. On the other hand, the authors observed that both concentrations increased MDA levels when associated with the potentially toxic metal $\mathrm{Cd}$ at $2.5 \mathrm{mg} \mathrm{kg}^{-1}$. The results suggest that the synergistic action between $\mathrm{Cd}$ and ENR may cause ROS accumulation, leading to antioxidant system imbalances and, consequently, increased lipid peroxidation levels as measured by MDA levels. As was observed in the present study, Li et al ( $\mathrm{Li}$ et al. 2016) reported decreased MDA levels on the $8^{\text {th }}$ week of the experiment, revealing a recovery of the initial effect.

Considering other approaches derived from the spread of environmental contamination by antibiotics, $\mathrm{Ni}$ et al. (2019) evaluated MDA alterations in zebrafish (Danio rerio) exposed to maduramicin, an ionophore antibiotic used as a coccidiostatic in poultry production. According to the authors, increases in MDA levels were observed in the liver following 14 days of exposure to $0.1,0.5$ and $2.5 \mathrm{mg} \mathrm{L}^{-1}$ and in the gills at 3 and 9 days following 0.5 and $2.5 \mathrm{mg} \mathrm{L}^{-1}$ exposures.

The results of lower trophic level exposures indicate significant changes even at lower antibiotic concentrations, in the order of parts per billion $(\mathrm{ppb})$. For example, increased lipid peroxidation levels were observed in the zooplankton species Daphnia magna exposed to CPX from $12.5 \mathrm{\mu g} \mathrm{L}^{-1}$ for 21 days (Dionísio et al. 2020). In addition, it is important to emphasize the possibility of a synergistic effect between the multiple antibiotics used in poultry production, even at low concentrations. Wang et al. (Wang et al. 2019a), observed 1.8- and 3.1-fold increases in MDA levels in the fresh water microalgae Chlorella vulgaris after exposure to $0.03 \mathrm{mg} \mathrm{L}^{-1}$ of erythromycin (ERY) and ENR, respectively. However, an almost 5.0-fold increase was reported following exposure to an ERY and ENR mixture at $0.01 \mathrm{mg} \mathrm{L}^{-1}$. 


\subsection{Principal Component Analysis (PCA)}

The principal component analysis associated the antioxidant system biomarkers SOD, CAT, GST, GSH and MDA, with the two main components sharing $71.4 \%$ of the total variance (Fig. 4). A weak association was observed between the principal component 1 (PC1) and MDA, and a moderate association was noted between SOD, CAT and GST, evidenced by the factor loads of these variables $(0.30,0.55,0.58$ and 0.53 , respectively). The results suggest that exposure to poultry litter resulted in ROS production and accumulation, leading to increased SOD and CAT activities. Increased GST activity was also noted, evidencing a possible metabolization and elimination process of the multiple stressors present in poultry litter, as well as lipid peroxidation by-products (Fig. 3). However, it is possible that GST activity in response to the presence of ENR and its metabolite CPX may have generated other reactive biotransformation products, leading to lipid peroxidation, in agreement with the positive association between MDA and SOD, CAT and GST detected in the first principal component.

The second main component $(\mathrm{PC} 2=23.9 \%)$ presented the highest factor loads for GSH $(-0.78)$ and MDA (0.57). Factorial loads with opposite signs indicate an inverse correlation between these biomarkers $(\rho 2=$ $-0.24 ; p<0.05)$. Furthermore, according to the Pearson correlation analysis, a negligible correlation was observed between GSH and GST ( $22=0.074 ; p<0.05$ ), indicating demands for GSH in the glutathione redox cycle instead of its use as a GST substrate. This indicates that the glutathione redox cycle is an important system acting in tandem with CAT against $\mathrm{H}_{2} \mathrm{O}_{2}$ accumulation. However, considering the correlation between GSH and MDA (PC2), it is possible that GSH is predominant in this process (Sies 1999; Bhagat et al. 2016; Simioni et al. 2018). Thus, GSH depletion seems to be more important in initiating lipid peroxidation in poultry litter-exposed earthworms when compared to decreased SOD and CAT activities.

\subsection{Biological health status (BHS)}

The application of poultry litter or manure as soil fertilizer differs according to the type of soil, crop, management and litter availability for farmers (Parente et al. 2020). In addition, the application frequency of organic fertilizers also depends on latitude, since tropical climates favor crop production throughout the entire year. Based on the physico-chemical properties of agricultural soils, the Brazilian Agricultural Research Corporation has established a $10 \mathrm{~g} \mathrm{~kg}^{-1}$ limit (equivalent to $20 \mathrm{t} \mathrm{ha}^{-1}$ ) for poultry litter applications in agricultural soils (Freire et al. 2013). However, the amount applied in the field can be much higher, with applications of $600 \mathrm{~g}$ of poultry litter per seedling having been reported (Bhering et al. 2020), resulting in the application of $42 \mathrm{t} \mathrm{ha}^{-1}$ based on crops containing 70,000 seedlings per hectare. An even higher application was estimated in a field study carried out in China, of $45 \mathrm{t} \mathrm{ha}^{-1}$ of pig manure (Zhao et al. 2020). In view of such a diverse exposure scenario, we estimated the BHS of earthworms based on the $\mathrm{BRI}$, integrating the responses observed following the three exposure concentrations of $5.0,10$ and $20 \mathrm{~g}$ $\mathrm{kg}^{-1}$ (equivalent to 10, 20 and $40 \mathrm{t} \mathrm{ha}^{-1}$ ) (Fig. 5). 
The results indicate that exposure to FQ-contaminated poultry litter induced more critical responses during the first month (Day 7 -28: major alterations), when compared to the milder responses following the second month of exposure (Day 35 - 56: moderate alterations). Therefore, a recovery trend is noted throughout the experiment, which may be associated to the gradual metabolization of the antibiotics present in the poultry litter. In this regard, Mougin et al. (2013) reported that Aporrectodea caliginosa and A. longa earthworms increased $\left[2-{ }^{14} \mathrm{C}\right]$-CPX mineralization up to 8 -fold in a soil experiment lasting 84 days. Unlike the trend observed for the other investigated biomarkers, GSH maintained high antioxidant system activity throughout the experiment, with AL ranging from major ( $1^{\text {st }}$ month) to severe $\left(2^{\text {nd }}\right.$ month). On the other hand, MDA presented only slight alterations with the grouped results, indicating that lipid peroxidation was not the main endpoint associated to oxidative effects.

\section{Conclusions}

Poultry litter caused chronic effects on the Eisenia andrei antioxidant system during 56 days of exposure, and the observed increases in enzyme activities (SOD, CAT and GSH) and GSH levels demonstrate that poultry litter exposure induced ROS production and accumulation in these organisms.

The PCA indicated GST activity as paramount in the elimination of xenobiotics present in the poultry litter, although its positive association with MDA as a proxy for LPO suggests the production of reactive metabolites. The PCA also pointed out that GSH was the main responsible in avoiding ROS accumulation via the glutathione redox cycle, since an opposite association and negative correlation with MDA was observed.

The evaluation of the Biological Health Status, integrating all assessed biomarker responses, indicated severe GSH alterations at the end of the experiment. On the other hand, a trend towards SOD, CAT and GSH attenuation was noted, in addition to only slight MDA alterations, at the end of the experiment. It is, however, important to note that the results presented herein are derived from a single poultry litter application. Therefore, it is possible that successive applications, mainly in short cycle crops (four or more harvests per year), may reduce the resilience and the long-term recovery capacity of the evaluated biomarkers. In view of these results, further studies are required concerning the sublethal effects of poultry litter in different taxonomic groups, contributing to the establishment of regulations aimed at the environmentally safe application of poultry litter in agricultural soils.

\section{Declarations}

\section{Acknowledgments}

This research was partially financed by the Conselho Nacional de Desenvolvimento Científico e Tecnológico (CNPq)/Ministério da Ciência, Tecnologia, Inovações e Comunicações (MCTIC) and the Coordenação de Aperfeiçoamento de Pessoal de Nível Superior - Brasil (CAPES). CETP holds a postdoctoral grant from (CAPES), OM holds a "Cientista do Nosso Estado" grant from the Fundação de 
Amparo à Pesquisa do Estado do Rio de Janeiro (FAPERJ) and EMS holds a "Jovem Cientista do Nosso Estado" grant from the Fundação de Amparo à Pesquisa do Estado do Rio de Janeiro (FAPERJ - Project E26/203.165/2017).

\section{Ethics approval and consent to participate}

\section{Not applicable}

\section{Consent for publication}

\section{Not applicable}

\section{Availability of data and materials}

\section{Not applicable}

\section{Competing interests}

The authors declare that they have no competing interests

\section{Authors' contributions}

Sidney Fernandes Sales Júnior: Investigation, Formal analysis, Writing - Original Draft; Evelyn Oliveira da Silva: Data Curation, Formal analysis; Gabriel de Farias Araujo: Data Curation, Formal analysis; Lorena Oliveira Souza Soares: Data Curation, Formal analysis; Cláudio ET Parente: Data Curation, Formal analysis; Olaf Malm: Investigation, Writing - Review \& Editing; Enrico Mendes Saggioro: Conceptualization, Resources, Writing - Review \& Editing, Supervision, Project administration, Funding acquisition; Fábio Veríssimo Correia: Methodology, Supervision, Funding acquisition. All authors read and approved the final manuscript

\section{References}

ABPA (2020) Brazilian Association of Animal Protein, 2020. Annual Report.

Aebi H (1984) Oxygen Radicals in Biological Systems. Methods Enzymol 105:121-126. doi: 10.1016/S0076-6879(84)05016-3

ASTM (2012) ASTM E1676-12: Standard Guide for Conducting Laboratory Soil Toxicity or Bioaccumulation Tests with the Lumbricid Earthworm Eisenia Fetida and the Enchytraeid Potworm Enchytraeus albidus. ASTM International, West Conshohocken, PA

Bakare AA, Patel S, Pandey AK, et al (2012) DNA and oxidative damage induced in somatic organs and tissues of mouse by municipal sludge leachate. Toxicol Ind Health 28:614-623. doi: 
Barbosa MR, Silva MM de A, Willadino L, et al (2014) Geração e desintoxicação enzimática de espécies reativas de oxigênio em plantas. Ciência Rural 44:453-460. doi: 10.1590/S0103-84782014000300011

Barreiros ALBS, David JPJM, David JPJM (2006) Estresse oxidativo: Relação entre Geração de espécies reativas e defeda do organismo. Quim Nov 29:113-123

Bhagat J, Ingole BS, Singh N (2016) Glutathione s-transferase, catalase, superoxide dismutase, glutathione peroxidase, and lipid peroxidation as biomarkers of oxidative stress in snails: A review. Invertebr Surviv J 13:336-349

Bhering AS, Carmo MGF, Coelho IS, et al (2020) Soil management in a mountain agroecosystem and clubroot disease. Plant Pathol 69:302-309. doi: 10.1111/ppa.13123

Bolan NS, Szogi AA, Chuasavathi T, et al (2010) Uses and management of poultry litter. Worlds Poult Sci J 66:673-698. doi: 10.1017/S0043933910000656

Bradford MM A rapid and sensitive method for the quantitation of microgram quantities of protein utilizing the principle of protein-dye binding. Anal Biochem 72:248-54. doi: 10.1016/00032697(76)90527-3

Cook KL, Netthisinghe AMP, Gilfillen RA (2014) Detection of Pathogens, Indicators, and Antibiotic Resistance Genes after Land Application of Poultry Litter. J Environ Qual 43:1546-1558. doi: $10.2134 /$ jeq2013.10.0432

Curi LM, Peltzer PM, Martinuzzi C, et al (2017) Altered development, oxidative stress and DNA damage in Leptodactylus chaquensis (Anura: Leptodactylidae) larvae exposed to poultry litter. Ecotoxicol Environ Saf 143:62-71. doi: 10.1016/j.ecoenv.2017.05.007

Dionísio R, Daniel D, Alkimin GD de, Nunes B (2020) Multi-parametric analysis of ciprofloxacin toxicity at ecologically relevant levels: Short- and long-term effects on Daphnia magna. Environ Toxicol Pharmacol 74:103295. doi: 10.1016/j.etap.2019.103295

Dróżdż D, Wystalska K, Malińska K, et al (2020) Management of poultry manure in Poland - Current state and future perspectives. J Environ Manage 264:110327. doi: 10.1016/j.jenvman.2020.110327

Esterbauer H, Cheeseman KH (1990) Determination of aldehydic lipid peroxidation products: malonaldehyde and 4-hydroxynonenal. Methods Enzymol 186:407-421

FAO (2020) Meat Market Review - Emerging trends and outlook

Fortuna A, Oreamuno MAA, Maria G, et al (2020) Food Outlook 2020 -Biannaul Report on Global Food Markets 
Freire LR., Balieiro FC., Zonta E., et al (2013) Calagem e Adubação do Estado do Rio de Janeiro. Embrapa Solos, Rio de Janeiro

Furtula V, Farrell EG, Diarrassouba F, et al (2010) Veterinary pharmaceuticals and antibiotic resistance of Escherichia coli isolates in poultry litter from commercial farms and controlled feeding trials. Poult Sci 89:180-188. doi: 10.3382/ps.2009-00198

Gao Y, Sun X, Sun Z, et al (2008) Toxic effects of enrofloxacin on growth rate and catalase activity in Eisenia fetida. Environ Toxicol Pharmacol 26:177-180. doi: https://doi.org/10.1016/j.etap.2008.03.004

Gu D, Feng Q, Guo C, et al (2019) Occurrence and Risk Assessment of Antibiotics in Manure, Soil, Wastewater, Groundwater from Livestock and Poultry Farms in Xuzhou, China. Bull Environ Contam Toxicol 103:590-596. doi: 10.1007/s00128-019-02692-0

Habig WH, Pabst MJ, Jakoby WB (1974) Glutathione S-Transferases: The first enzymatic step in mercapturic acid formation. J Biol Chemestry 249:7130-7139

Hagger JA, Jones MB, Lowe D, et al (2008) Application of biomarkers for improving risk assessments of chemicals under the Water Framework Directive: A case study. Mar Pollut Bull 56:1111-1118. doi: 10.1016/j.marpolbul.2008.03.040

Hayes JD, Flanagan JU, Jowsey IR (2005) Glutathione transferases. Annu Rev Pharmacol Toxicol 45:5188. doi: 10.1146/annurev.pharmtox.45.120403.095857

Huber PC, Almeida WP, Fátima Â de (2008) Glutathione and related enzymes: biological roles and importance in pathological processes. Quim Nova 31:1170-1179. doi: 10.1590/S010040422008000500046

Kanani F, Heidari MD, Gilroyed BH, Pelletier N (2020) Waste valorization technology options for the egg and broiler industries: A review and recommendations. J Clean Prod 262:121129. doi:

10.1016/j.jclepro.2020.121129

Leal RMP, Figueira RF, Tornisielo VL, Regitano JB (2012) Occurrence and sorption of fluoroquinolones in poultry litters and soils from São Paulo State, Brazil. Sci Total Environ 432:344-349. doi:

10.1016/j.scitotenv.2012.06.002

Li C, Chen J, Wang J, et al (2015) Occurrence of antibiotics in soils and manures from greenhouse vegetable production bases of Beijing, China and an associated risk assessment. Sci Total Environ 521522:101-107. doi: 10.1016/j.scitotenv.2015.03.070

Li X, Wang M, Chen W, Jiang R (2019) Evaluation of combined toxicity of Siduron and cadmium on earthworm (Eisenia fetida) using Biomarker Response Index. Sci Total Environ 646:893-901. doi: 10.1016/j.scitotenv.2018.07.380 
Li Y, Tang H, Hu Y, et al (2016) Enrofloxacin at environmentally relevant concentrations enhances uptake and toxicity of cadmium in the earthworm Eisenia fetida in farm soils. J Hazard Mater 308:312-320. doi: 10.1016/j.jhazmat.2016.01.057

Li Y, Zhao C, Lu X, et al (2018) Identification of a cytochrome P450 gene in the earthworm Eisenia fetida and its mRNA expression under enrofloxacin stress. Ecotoxicol Environ Saf 150:70-75. doi:

10.1016/j.ecoenv.2017.12.020

Maccari AP, Corá Segat J, Testa M, et al (2020) The effect of composted and non-composted poultry litter on survival and reproduction of Folsomia candida. Int J Recycl Org waste Agric 9:99-105. doi:

10.30486/ijrowa.2020.1885804.1012

Mougin C, Cheviron N, Repincay C, et al (2013) Earthworms highly increase ciprofloxacin mineralization in soils. Environ Chem Lett 11:127-133. doi: 10.1007/s10311-012-0385-z

Nations U (2020) The Sustainable Development Goals Report 2020. UN

Nguyen B-AT, Chen Q-L, He J-Z, Hu H-W (2020) Oxytetracycline and Ciprofloxacin Exposure Altered the Composition of Protistan Consumers in an Agricultural Soil. Environ Sci Technol 54:9556-9563. doi: 10.1021/acs.est.0c02531

Ni H, Peng L, Gao X, et al (2019) Effects of maduramicin on adult zebrafish (Danio rerio): Acute toxicity, tissue damage and oxidative stress. Ecotoxicol Environ Saf 168:249-259. doi:

10.1016/j.ecoenv.2018.10.040

Nie X, Wang X, Chen J, et al (2008) RESPONSE OF THE FRESHWATER ALGA CHLORELLA VULGARIS TO TRICHLOROISOCYANURIC ACID AND CIPROFLOXACIN. Environ Toxicol Chem 27:168. doi: 10.1897/07028.1

Niva CC, Niemeyer JC, Júnior FMRDS, et al (2016) Soil ecotoxicology in Brazil is taking its course. Environ Sci Pollut Res 23:11363-11378. doi: 10.1007/s11356-016-6597-1

OECD (1984) Test n 207: Earthworm, Acute Toxicity Tests. OECD Publishing, Washington, DC.

OECD (2016) Test $n^{\circ}$ 222: Earthworm Reproduction Test (Eisenia fetida/Eisenia andrei). OECD Publishing, Washington, DC.

Parente CE, Oliveira da Silva E, Sales Júnior SF, et al (2021) Fluoroquinolone-contaminated poultry litter strongly affects earthworms as verified through lethal and sub-lethal evaluations. Ecotoxicol Environ Saf 207:111305. doi: 10.1016/j.ecoenv.2020.111305

Parente CET, Brusdzenski GS, Zonta E, et al (2020) Fluoroquinolones and trace elements in poultry litter: estimation of environmental load based on nitrogen requirement for crops. J Environ Sci Heal Part B 55:1087-1098. doi: 10.1080/03601234.2020.1816794 
Parente CET, Sierra J, Martí E (2018) Ecotoxicity and Biodegradability of Oxytetracycline and Ciprofloxacin on Terrestrial and Aquatic Media. Orbital Electron J Chem 10:. doi:

10.17807/orbital.v10i4.1063

Parente CETT, Azeredo A, Vollú RE, et al (2019) Fluoroquinolones in agricultural soils: Multi-temporal variation and risks in Rio de Janeiro upland region. Chemosphere 219:409-417. doi:

10.1016/j.chemosphere.2018.11.184

Piva F, Ciaprini F, Onorati F, et al (2011) Assessing sediment hazard through a weight of evidence approach with bioindicator organisms: A practical model to elaborate data from sediment chemistry, bioavailability, biomarkers and ecotoxicological bioassays. Chemosphere 83:475-485. doi:

10.1016/j.chemosphere.2010.12.064

Pugazhendhi A, Dhanarani S, Shankar C, et al (2017) Electrophoretic pattern of glutathione S-transferase (GST) in antibiotic resistance Gram-positive bacteria from poultry litter. Microb Pathog 110:285-290. doi: 10.1016/j.micpath.2017.07.003

Radetski CM, Ferrari B, Cotelle S, et al (2004) Evaluation of the genotoxic, mutagenic and oxidant stress potentials of municipal solid waste incinerator bottom ash leachates. Sci Total Environ 333:209-216. doi: 10.1016/j.scitotenv.2004.05.015

Riaz L, Mahmood T, Khalid A, et al (2018) Fluoroquinolones (FQs) in the environment: A review on their abundance, sorption and toxicity in soil. Chemosphere 191:704-720. doi:

10.1016/j.chemosphere.2017.10.092

Rivier P-A, Havranek I, Coutris C, et al (2019) Transfer of organic pollutants from sewage sludge to earthworms and barley under field conditions. Chemosphere 222:954-960. doi:

10.1016/j.chemosphere.2019.02.010

Saggioro EM, do Espírito Santo DG, Sales Júnior SF, et al (2019) Lethal and sublethal effects of acetamiprid on Eisenia andrei: Behavior, reproduction, cytotoxicity and oxidative stress. Ecotoxicol Environ Saf 183:109572. doi: 10.1016/j.ecoenv.2019.109572

Sales Junior SF, Vallerie Q, de Farias Araujo G, et al (2020) Triclocarban affects earthworms during longterm exposure: Behavior, cytotoxicity, oxidative stress and genotoxicity assessments. Environ Pollut 115570. doi: 10.1016/j.envpol.2020.115570

Santos Dalólio F, da Silva JN, Carneiro de Oliveira AC, et al (2017) Poultry litter as biomass energy: A review and future perspectives. Renew Sustain Energy Rev 76:941-949. doi: 10.1016/j.rser.2017.03.104

Sidhu H, O'Connor G, Ogram A, Kumar K (2019) Bioavailability of biosolids-borne ciprofloxacin and azithromycin to terrestrial organisms: Microbial toxicity and earthworm responses. Sci Total Environ 650:18-26. doi: 10.1016/j.scitotenv.2018.09.004

Page $17 / 24$ 
Sies H (1999) Glutathione and its role in cellular functions. Free Radic Biol Med 27:916-921. doi: 10.1016/S0891-5849(99)00177-X

Simioni C, Zauli G, Martelli AM, et al (2018) Oxidative stress: role of physical exercise and antioxidant nutraceuticals in adulthood and aging. Oncotarget 9:17181-17198. doi: 10.18632/oncotarget.24729

Testa M, Silva AS da, Segat JC, et al (2020) Impacts on reproduction of Enchytraeus crypticus in fertilized soils with chicken litter treated with synthetic and natural insecticide. Environ Toxicol Pharmacol 78:103386. doi: 10.1016/j.etap.2020.103386

Vollú RERE, Cotta SRSR, Jurelevicius D, et al (2018) Response of the Bacterial Communities Associated With Maize Rhizosphere to Poultry Litter as an Organomineral Fertilizer. Front Environ Sci 6:. doi: $10.3389 /$ fenvs.2018.00118

Wang C, Rong H, Liu H, et al (2018) Detoxification mechanisms, defense responses, and toxicity threshold in the earthworm Eisenia foetida exposed to ciprofloxacin-polluted soils. Sci Total Environ 612:442-449. doi: $10.1016 /$ j.scitotenv.2017.08.120

Wang G, Zhang Q, Li J, et al (2019a) Combined effects of erythromycin and enrofloxacin on antioxidant enzymes and photosynthesis-related gene transcription in Chlorella vulgaris. Aquat Toxicol 212:138-145. doi: 10.1016/j.aquatox.2019.05.004

Wang L, Zhang W, Wang J, et al (2019b) Toxicity of enrofloxacin and cadmium alone and in combination to enzymatic activities and microbial community structure in soil. Environ Geochem Health 41:25932606. doi: 10.1007/s10653-019-00307-5

Wei R, He T, Zhang S, et al (2019) Occurrence of seventeen veterinary antibiotics and resistant bacterias in manure-fertilized vegetable farm soil in four provinces of China. Chemosphere 215:234-240. doi: 10.1016/j.chemosphere.2018.09.152

Wei Z, Wang J, Zhu L, et al (2018) Toxicity of enrofloxacin, copper and their interactions on soil microbial populations and ammonia-oxidizing archaea and bacteria. Sci Rep 8:5828. doi: 10.1038/s41598-01824016-8

Wilhelm Filho D, Torres MA, Zaniboni-Filho E, Pedrosa RC (2005) Effect of different oxygen tensions on weight gain, feed conversion, and antioxidant status in piapara, Leporinus elongatus (Valenciennes, 1847). Aquaculture 244:349-357. doi: 10.1016/J.AQUACULTURE.2004.11.024

Wolff SP, Dean RT (1987) Glucose autoxidation and protein modification. The potential role of autoxidative glycosylation' in diabetes. Biochem J 245:243-250. doi: 10.1042/bj2450243

Yang R, Wang J, Zhu L, et al (2021) Effects of interaction between enrofloxacin and copper on soil enzyme activity and evaluation of comprehensive toxicity. Chemosphere 268:129208. doi:

10.1016/j.chemosphere.2020.129208

Page $18 / 24$ 
Yang X, Li Y, Wang X (2020) Effects of ciprofloxacin exposure on the earthworm Eisenia fetida. Environ Pollut 262:114287. doi: https://doi.org/10.1016/j.envpol.2020.114287

Zhang Y-J, Hu H-W, Chen Q-L, et al (2019) Transfer of antibiotic resistance from manure-amended soils to vegetable microbiomes. Environ Int 130:104912. doi: 10.1016/j.envint.2019.104912

Zhao F, Chen L, Yang L, et al (2020) Effects of land use and rainfall on sequestration of veterinary antibiotics in soils at the hillslope scale. Environ Pollut 260:114112. doi: 10.1016/j.envpol.2020.114112

\section{Figures}



$\square$ Day 7
$\square$ Day 14
ZD Day 21
$\square$ Day 28
Day 35
Day $49 \square$ Day 56
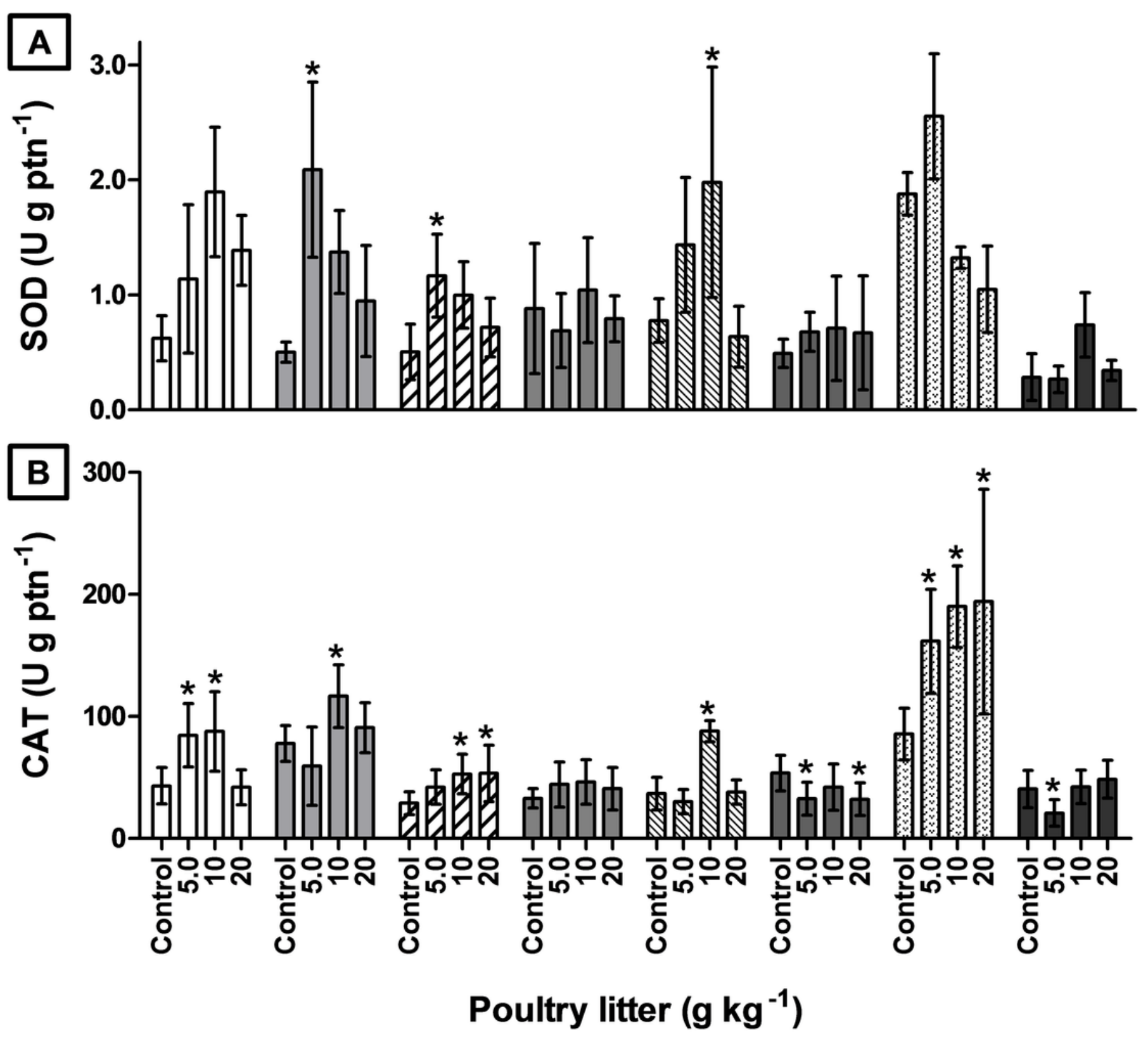

Figure 1

A-B Mean variations in superoxide dismutase (SOD) and catalase (CAT) activities in earthworms exposed to $5.0,10$ and $20 \mathrm{~g} \mathrm{~kg}-1$ of FQ-contaminated poultry litter during a 56-day chronic test. Error bars represent standard deviations. *Statistically significant values when compared to their respective controls (ANOVA $p \leq 0.05$ ). 


\section{$\square$ Day $7 \square$ Day $14 \quad \square$ Day $21 \quad \square$ Day 28 \\ Day $35 \square$ Day $42 \square$ Day $49 \square$ Day 56}

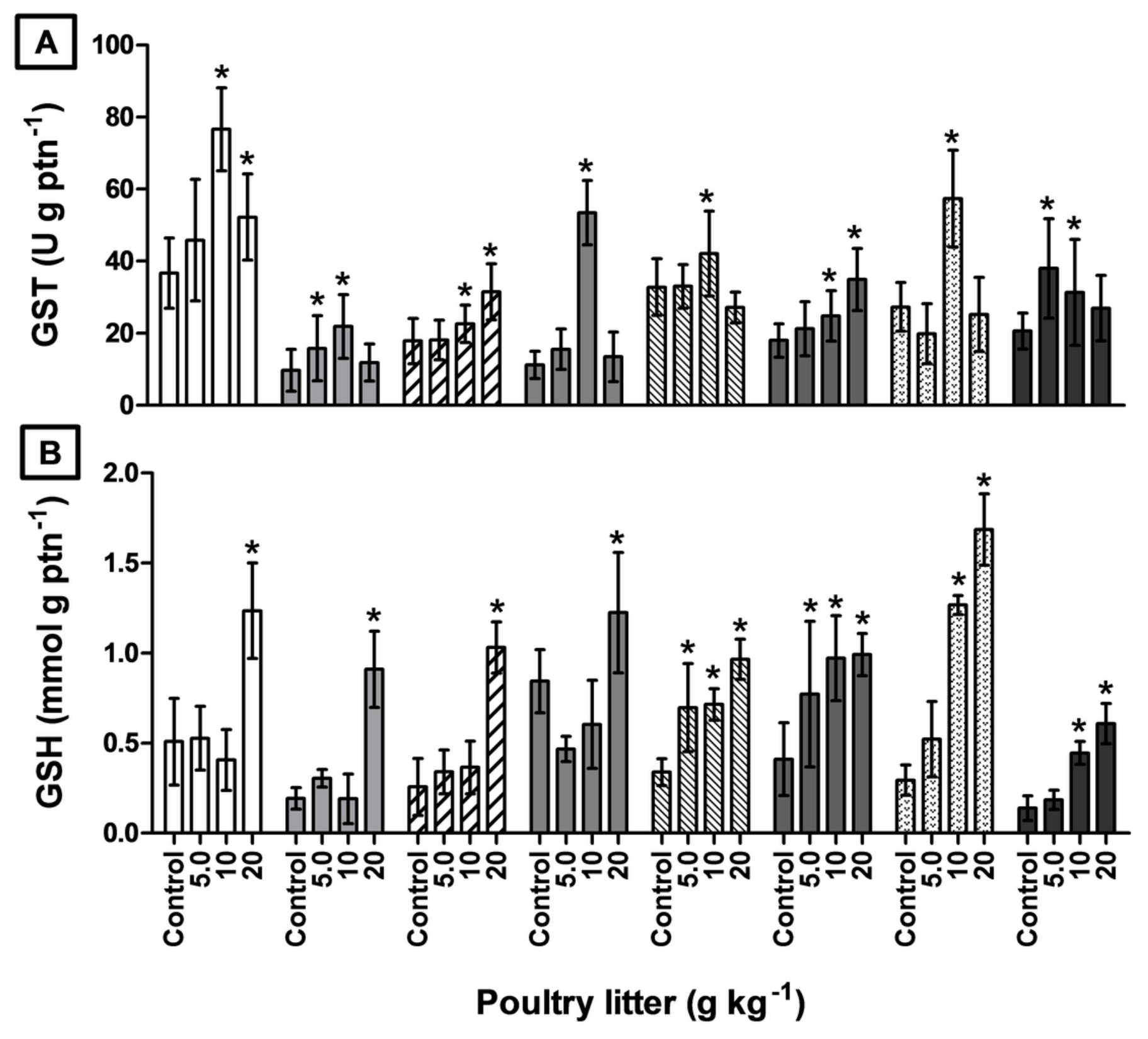

Figure 2

A-B Mean variation in glutathione-S-transferase (GST) activity and reduced glutathione (GSH) levels in earthworms exposed to 5.0, 10 and $20 \mathrm{~g} \mathrm{~kg}-1$ of FQ-contaminated poultry litter during a 56-day chronic test. Error bars represent the standard deviations. *Statistically significant values when compared to their respective controls (ANOVA $p \leq 0.05$ ). 


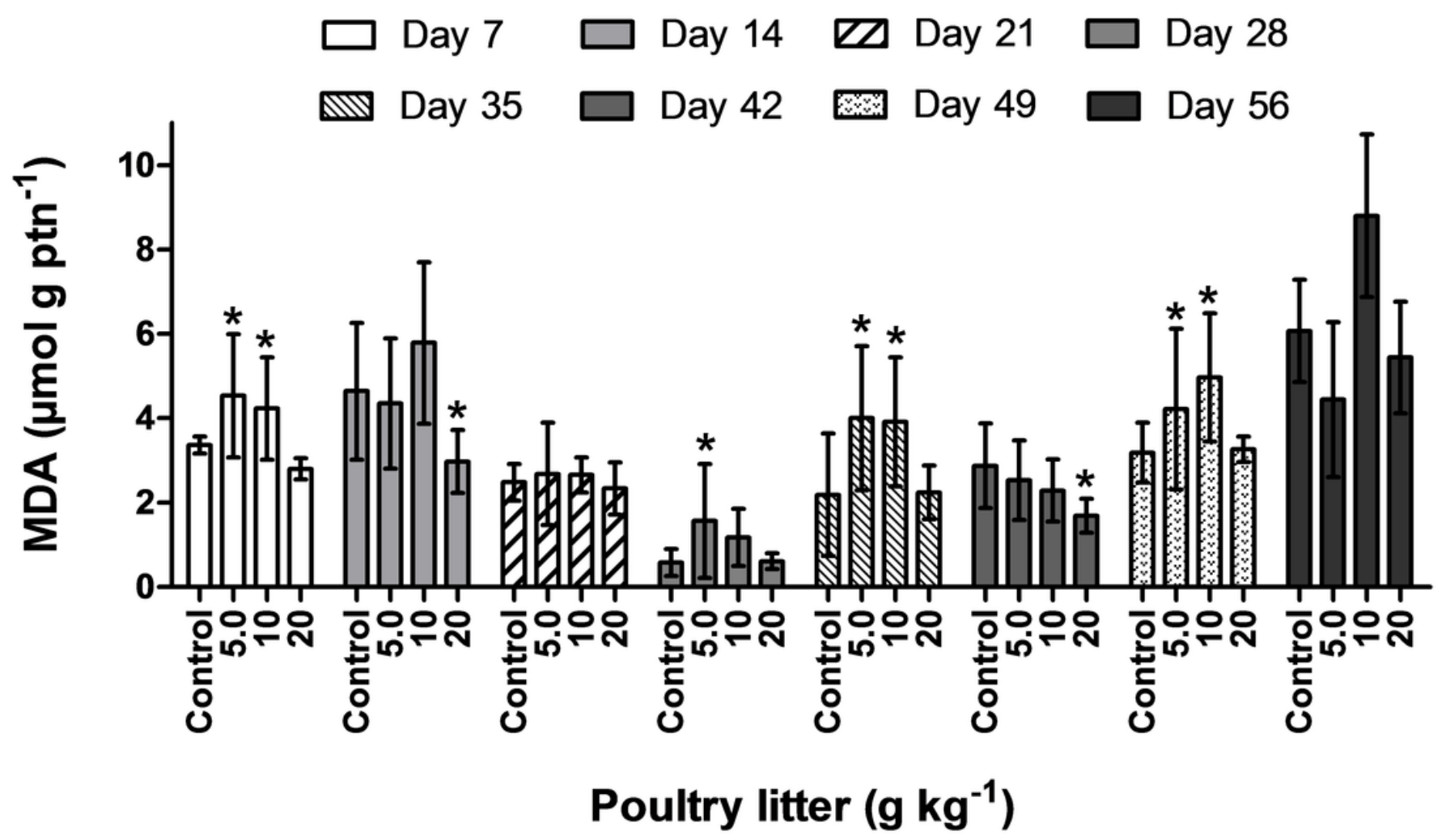

Figure 3

Mean variation of malondialdehyde (MDA) levels in earthworms exposed to $5.0,10$ and $20 \mathrm{~g} \mathrm{~kg}-1$ of FQcontaminated poultry litter during a 56-day chronic test. Error bars represent the standard deviation. *Statistically significant values when compared to their respective controls (ANOVA $p \leq 0.05$ ). 


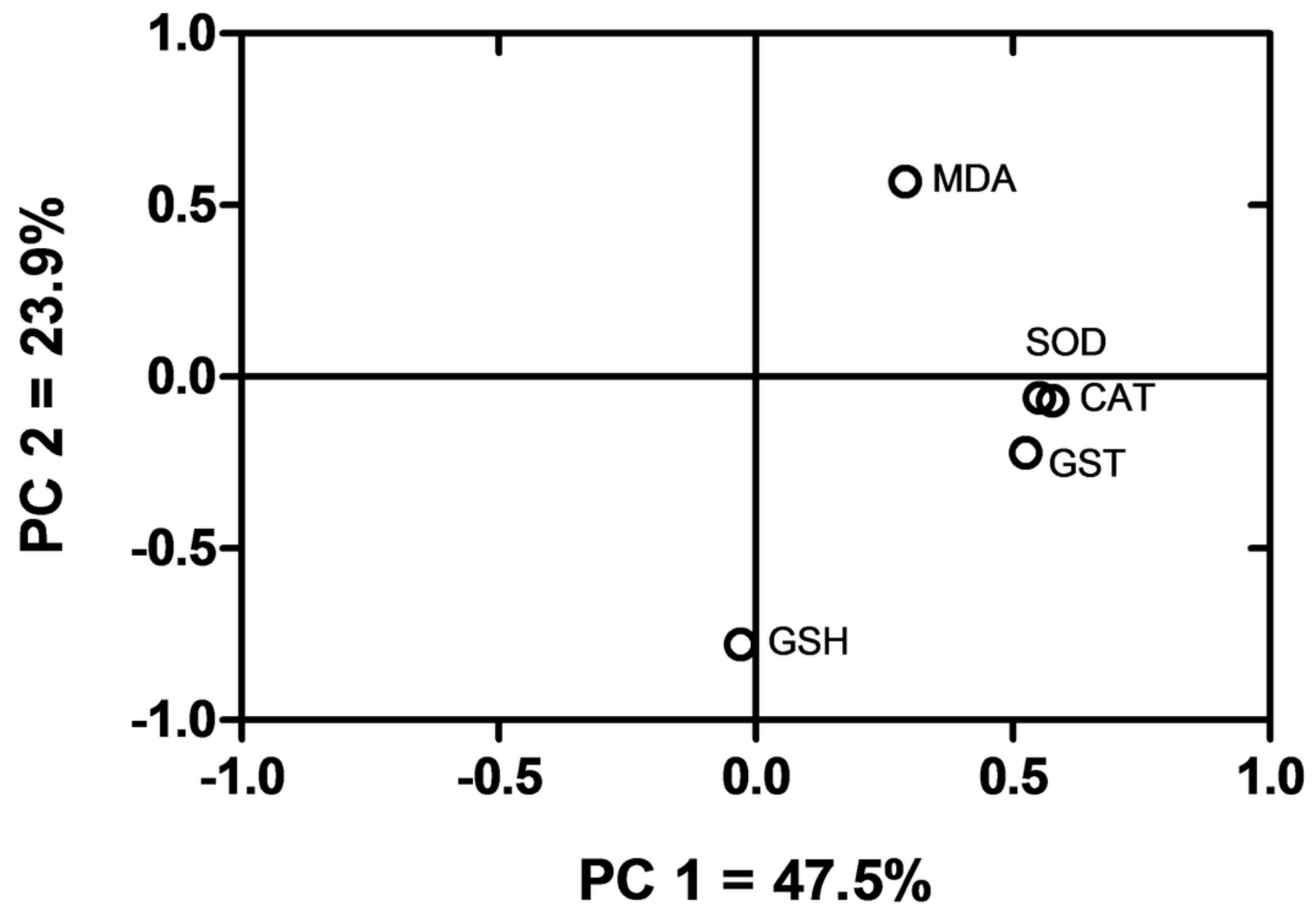

Figure 4

Principal Component Analysis of the antioxidant system variables superoxide dismutase (SOD) catalase (CAT), glutathione-S-transferase (GST), reduced glutathione (GSH) and malondialdehyde (MDA) explained by factors PC1 and PC2. Bartlett $\mathrm{p}$-value $<0.0001 . \mathrm{KMO}=0.71$. 


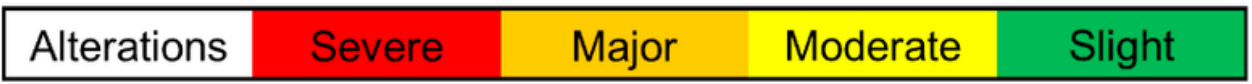

\begin{tabular}{|c|c|c|c|c|c|c|c|c|}
\hline $\begin{array}{l}\text { Biomarker } \\
\text { responses }\end{array}$ & Day 7 & Day 14 & Day 21 & Day 28 & Day 35 & Day 42 & Day 49 & Day 56 \\
\hline BRI (weekly) & 2.60 & 2.60 & 2.89 & 2.88 & 2.64 & 2.79 & 2.53 & 3.20 \\
\hline BRI (monthly) & \multicolumn{4}{|c|}{2.74} & \multicolumn{4}{|c|}{2.79} \\
\hline SOD & \multicolumn{4}{|c|}{2.08} & \multicolumn{4}{|c|}{2.83} \\
\hline CAT & \multicolumn{4}{|c|}{2.75} & \multicolumn{4}{|c|}{2.83} \\
\hline GST & \multicolumn{4}{|c|}{2.42} & \multicolumn{4}{|c|}{3.25} \\
\hline GSH & \multicolumn{4}{|c|}{2.67} & \multicolumn{4}{|c|}{1.33} \\
\hline MDA & \multicolumn{4}{|c|}{3.17} & \multicolumn{4}{|c|}{3.08} \\
\hline
\end{tabular}

Figure 5

Biological health status (BHS) of earthworms exposed to poultry litter based on the biomarker response index (BRI) per week, month (Day 7 -28; Day 35 - 56) and for each biomarker.

\section{Supplementary Files}

This is a list of supplementary files associated with this preprint. Click to download.

- Supplementarymaterial.docx 